\title{
La más sublime Poetisa de América y del Sigro XVII Sor Juana Ines de la Cruz
}

\section{Germán Arce M.}

"La encina secular de la literatura española, escribe el Académico D. Ramón Perés, que antes no ostentaba más que el viejo y venerable tronco, empezó a echar retoños que fueron convirtiéndose en tantos otros árboles frondosos. Fue allá en aquella América que dieron a España los grandes conquistadores y sacrificados misioneros, donde vemos estos árboles tan gigantes y poderosos que bien se pueden comparar a los gigantes de la literatura de la Madre Patria." Un escritor francés, Max Daireaux, dice que "escribir la historia de la poesía de América Latina, es escribir la historia de su misma literatura. Por lo abundante y seplendorosa, la poesía domina el movimiento literario del Continente, lo unifica y sólo en ella cabe descubrir las escuelas, las tendencias, los movimientos comunes a todos los países de la América Latina, desde sus orígenes hasta nuestros días.".

Pero de entre estos árboles frondosos y de entre estos nuevos gigantes, el que más sobresale de todos es una humilde mujer mexicana: Sor Juana Inés de la Cruz: la mayor en su época en lengua castellana. La lectura de esta escondida poetisa no puede ser más interesante. Todo en aquella mujer es extraordinario, todo se halla fuera de los límites de lo vulgar. Tiene el don, desde niña, de la inspirada originalidad y de la gracia femenina. Posee una ilustración y recidumbre completamante 
masculinas, pero acompañadas del garbo, la dulzura y el sentimiento de la mujer, y de la vehemencia y ocurrente expresión de una criolla que ha sido educada entre gentes cortesanas.

Nació Juana Asbaje, o, según D. Miguel Unamuno, Juana Asuaje, apellido todavía existente en los paises vascos: Asua con la terminación castellana, nació, digo, el 12 de Noviembre de 1651 en la pequeña aldea de Nepantla, en la alquería de San Miguel, en México, de padre español y de madre criolla. A los tres años escasos aprendió a leer, a los siete escribía ya con afición. A los ocho años compuso una Loa con todas las cualidades que requiere un cabal poema, según lo afirman testigos de aquel entonces. A los diecisiete años ingresó en el convento de las religiosas de San Jerónimo en la ciudad de México, donde permaneció hasta su muerte ocurrida en el 1695, a causa de una epidemia, al ayudar a otros enfermos. Tenía tan sólo 44 años. Sor Juana pertenece plenamente a la historia de la literatura española, en el sentido más exacto de la palabra, pues el hogar solariego de su habla y de su sangre estaba en España, sin que ello contradiga ni pueda atenuar el légitimo orgullo de México al contarla entre sus hijos más predilectos y más célebres. Los mexicanos están enamorados de esta Musa, como los españoles lo estamos de Santa Teresa. Pero ambas son poetisas que rompiendo el silencio de sus celdas, hacen oír su sonora y sublime voz más allá de las fronteras y de los mares, pues escriben para todas las naciones y para todos los hombres, dándonos cada una su mensaje peculiar.

Las mayores aportaciones a la vida, a la obra y a la bibliografía de Sor Juana, son mexicanas: Entre ellas destacan la primera biografía de esta poetisa, escrita por el P. Diego Calleja, y su 82 
La más sublime Poetisa de América y del Siglo XVII Sor Juana propia autobiografía, tan detalladamente descrita en la famosa carta a Sor Filomena de la Cruz, seudónimo de D. Manuel Fernández, Obispo de Puebla : Este documento es la fuente más sincera, auténtica y copiosa para los estudios de esta monja.

Nuestro Menéndez y Pelayo la consagró unas páginas magistrales en su Antología de poetas Hispanos-americanos. El gran humanista, universalmente conocido, Carl Vossler, la dedicó un sagaz estudio en su libro dedicado a los grandes clásicos españoles, y tradujo al alemán uno de sus Autos: Auto Sacramental del Divino Narciso. Sor Juana fue, desde su juventud, "una niña prodigio", como la llama el gran J.M. Pemán. Estaba dotada de una facilidad monstruosa. Podía permitirse, como Lope de Vega, hacer poesías "sólo para probar la pluma". Si Lope escribe un soneto, sólo para disculparlo en el último verso: "Perdona, Favio, que probé la pluma", Sor Juana se permite asegurar en un romance :

"Y para probar la pluma, instrumento de mi oficio, hice versos, como quien hace lo que hacer no quiso".

Sor Juana es la mujer que nació para estudiar, para escribir poesías. El primero y grande amor de Sor Juana fue la Sabiduría. Su vocación fue la ciencia y la poesía: me atrevo a decir que ella fue una digna y alta representante del "intelectualismo" típico del siglo XVII.

Sor Juana no tiene vocación para el matrimonio, posee un ansia creciente de estudio y halla la solución, digna y cristiana, de entrar en un convento, especie de cenobio laico. En este cenobio, su afán explorador de nuevos mundos intelectuales y 
su amistad con la Virreina, que lo era entonces la discreta Marquesa de Mancera, le proporcionaron medios para adquirir una perfecta biblioteca particular con más de 4.000 libros, amén de todo un laboratorio de física y matemáticas experimentales. La "décima Musa y la poetisa americana," como se la suele llamar, sabía lenguas, teología, filosofía y ciencias naturales-exactas. Su celda era un "depósito" de libros y de aparatos de física. Sor Juana vivió en un ambiente de mucho más despejado intelectualismo que lo que suele creerse. La facilidad de estudio, nos la describe ella misma en unos versos que pone en boca de Leonor, en su comedia "Los empeños de una casa" :

$$
\begin{aligned}
& \text { "Inclinéme a los estudios } \\
& \text { desde mis primeros años } \\
& \text { con tan ardientes desvelos } \\
& \text { con tan ansiosos cuidados, } \\
& \text { que reduje a tiempo breve } \\
& \text { fatigas de mucho espacio." }
\end{aligned}
$$

Diecisiete años vivió nuestra poetisa en el mundo, pero el mundo en el que vivió, fue el mundo y la sociedad más excogidas de México, en el palacio mismo de la Virreina, quien la consideraba como a su propia hija por su ingenio, su rectitud y su honestidad.

Cuarenta años tendría aquella monja, cuando escribía en su mencionada carta al Obispo de Puebla, este hermoso concepto : "En cuanto a no estudiar absolutamente, como no cae debajo de mi potestad, no lo puedo hacer, porque, aunque no estudiaba en los libros, estudiaba en todas las cosas que Dios crió, sirviéndome ellas de letras, y de libro toda esta máquina universal". En la formación intelectual de Sor Juana, creo que hay que 
La más sublime Poetisa de América y del Siglo XVII Sor Juana distinguir tres momentos culturales : el momento rústico, en el que se cultiva su sensibilidad: su pueblo natal, rodeado de la más pura y bella naturaleza, sito entre dos volcanes, el Popocatepelt y el Ixtacihualt, que parece le proporcionaron el fuego de un amor humano, tal vez no correspondido, y aún más, el fuego divino y el amor a la literatura.

El momento cotesano, en el que virtualmente se enriquece el espíritu por el estudio. En breve tiempo aprende el latín tan bien que hasta puede hacer versos en esta difícil lengua. Domina la física y las matemáticas como un sabio. Finalmente el momento conventual donde cultiva la filosofía, la teología y el razonamiento que da estructura y profundidad a su sistema.

Nos parece sorprendente una edad tan corta en la corte de los Virreyes para adquirir tan grandes y vastos conocimientos del mundo, pero hay que contar con la precocidad, o montruosidad, como la llama Pemán, de la criolla y en la libertad de costumbres de aquella brillante sociedad.

Mucho se ha escrito y discutido sobre la dualidad de lo amoroso y lo religioso en Sor Juana. Sor Juana no es una santa como Santa Teresa. Es una mujer que quiere estudiar y que sabe conservar su decoro de mujer y de monja, sin entrar nunca en el castillo de las siete torres de la monja abulense. Su problema amoroso, ¿tiene necesariamente que tener un objeto personalizado? Sor Juana no escribe un diario de sus experiencias eróticas, sino que más bien parece situarse en un estado cultural de enamoramiento. Pero no obstante, la gloria seria y consistente de esta poetisa mexicana se apoya sobre una veintena de composiciones de amor, en gran parte sonetos, cuya frescura apasionante ha turbado a muchos comentaristas y que aún hoy 
sigue siendo un enigma su interpretación. Ella nos escribe :

"Mas, ¿ cuándo ¡ ay, gloría mía! mereceré gozar tu luz serena? ¿cuándo llegará el día que pongas dulce fin a tanta pena? ¿ cuándo veré tus ojos, dulce encanto, y de los mios secarás el llanto? ¿cuándo tu luz hermosa revestirá de gloria mis sentidos? ¿Y cuándo yo dichosa mis suspiros daré por bien perdidos, teniendo en poco el precio de mi llanto? ¡qué tanto ha de penar quien goza tanto!"

En otra poesía afirma :

"Si el imán de tus gracias atractivo sirve mi pecho de obediente acero, ¿ para qué me enamoras lisonjero, si has de burlarme luego fujitivo? Tan precisa es la apetencia que a ser amados tenemos, que aun sabiendo que no sirve nunca dejarla sabemos."

$\mathrm{Y}$ termina uno de sus romances amorosos con estos versos:

"Aquel que tuviera amor entenderá lo que digo".

Los versos de amor profano de Sor Juana son de los más suaves y delicados que han salido de pluma de mujer," dice Menéndez y Pelayo. Poco tiempo tuvo la monja antes de entrar en el convento para dedicarse al amor y tener ciertas aventuras, 86 
La más sublime Poetisa de América y del Siglo XVII Sor Juana pero, si aprendió el latín en tan sólo 20 lecciones, bien se puede afirmar que este "monstruo de la naturaleza" aprendiera el amor humano en tan poco tiempo.

Los años de experiencia mundana, pienso que fueron decisivos para la futura formación y producción de la poetisa americana. Nada desdice a su decoro el que amara y fuese amada. Ya Menéndez Pelayo notó en sus poesías amorosas una sinceridad y calor que deben suponer un conocimiento experimental de las pasiones. El mexicano Amado Nervo, en su intuición de poeta, pensaba que tales versos eran demasiado para figuración y ripio. Yo humildemente hago mía esta teoría, pues las quejas de celos, y sobre todo, en los sonetos en que habla del que la ama y del que la aborrece, tienen un aspecto inconfundible de ser producto o consecuencia de casos vividos por ella misma, y no de meras figuraciones. Sor Juana nació y vivió para dos realidades: Dios y la poesía, que se pueden reducir a una sola palabra: Amor. Y fue este amor el que la impulsó al estudio de las ciencias y de las artes.

El mismo Virrey, el Marqués de Mancera, se maravilla de su facilidad para las ciencias y la somete a un examen ante cuantos profesores y maestros quisieran acudir a la prueba. De todas las dificultades y preguntas, salió victoriosa y con ventaja notoria.

$\mathrm{Su}$ facilidad, como ya dije antes, de componer versos era infinita. Con plena sinceridad podría escribir a la Virreina al felicitarle las Pascuas :

"Si yo he de daros las Pascuas

¿qué viene a importar que sea

en verso o en prosa, o con

estas palabras o aquellas? 
Si es malo, yo no lo sé;

sé que nací tan poeta

que azotada, como Ovidio,

Suenan en metro mis quejas."

Cualidad distintiva de Sor Juanan fue la curiosidad, condición por cierto bien femenina, pero pocas veces aplicada por el bello sexo a la ciencia. En Sor Juana esta curiosidad es aliada acuciante de un espíritu crítico que parece preludiar la actitud mental que había de llevar al siglo XVIII a conclusiones excesivas. Sor Juana llegó a forjar un concepto de la unidad de la ciencia, que ella misma expone: Suponía que la teología era la corona de todo humano saber y así todas las demás ciencias eran como servidoras de esta ciencia trascendental, pero que todas eran necesarias para entenderla. Tenía una cultura extensa, monstruosa en todos los ramos de la ciencia, pero nunca escribió nada de profundo y ella nos dice el por qué :

"En perseguirme, mundo, ¿qué interesas?

¿En qué te ofendo, cuando sólo intento

poner bellezas en mi entendimiento

y no mi entendimiento en las bellezas?

Yo no estimo tesoros ni riquezas;

y así, siempre me causa más contento

poner riquezas en mi entendimiento

que no mi entendimiento en las riquezas."

Pero no fueron todas rosas para nuestra poetisa, que tuvo que pasar por la prueba del fuego, como todo ser humano.

El gran dolor y martirio que sufrió Sor Juana no fue el paso de la corte al claustro, sino la renuncia que le impusieron de sus aparatos de física y de todos los libros que llenaban su 88 
La más sublime Poetisa de América y del Siglo XVII Sor Juana grande celda. Esto sucedió ya en los últimos años de su vida, a raíz de unas páginas que osó publicar, con ingeniosas objeciones, contra el más famoso predicador y orador de entonces, el portugués P. Vieyra. Tuvo admiradores y fieles seguidores, pero tuvo muchos y potentes enemigos. Ella sacrificó lo que más apreciaba y dedicó los últimos 4 años de su vida a obras de caridad, en la que murió por sus hermanas.

La mayor gloria de la famosa monja estará siempre en su sublime y vasta producción literaria y especialmente, en sus poesías. Menéndez y Pelayo, su gran admirador, calificó de milagro la aparición de su ingenio poético. Estéril era el panorama literario en la península y sobre todo el poético. Pero aún lo era más en México, que no contaba en aquel tiempo ni con un solo autor que pudiera llevar el nombre de poeta. Como bien saben, reinaba en esa época el "culteranismo" o "gongorismo", en honor de su creador, el poeta D. Luis de Góngora, y al que pertenecen los más de los ingenios que compusiron versos inmediatamente tras él, es decir, hacia la segunda mitad del siglo XVII : el uso desbordado de neologismos, laticismos, metáforas y transposiciones que hacen muy difícil su comprensión, como se puede ver en las obras claves de Góngora: "Polifemo y Soledades". Sor Juana intentó imitar al maestro en su obra "Primer Sueño", poesía singular por su tema. Pero el influjo más avasallador lo ejerció Calderón de la Barca, que, desde su tribuna de mayor difusión, el teatro, impuso su retórica y su concepto racionalista de la poesía. Desde que Sor Juana empieza a componer versos, siente la presión de estas influencias y especialmente de la de Calderón. Cuando Sor Juana se abandona a su inspiración se encuentra en la ór- 
bita calderoniana; pero cuando quiere "gongorizar", lo ha de hacer muy sobre pensado. Al dejarse influir de Calderón, obraba Sor Juana espontáneamente y como algo suyo propio, mientras que para imitar a Góngora tenía que proponérselo y esmerarse en ello, como algo diferente de ella misma.

La polémica sobre las tachas y virtudes de las mujeres, que tanto lugar ocupa en todos nuestros géneros literarios, hasta el Renacimiento, es acallada al introducirse el italianismo en nuestras poesías. Es curioso que Sor Juana Inés de la Cruz la resucite en la más popular de sus composiciones. Aunque es Gil Polo, quien en su "Diana Enamorada" viene a tomar en cuenta la polémica y plantea la defensa de la mujer exactamente en la misma posición extratégica en la que Sor Juana ha de situarse para lanzar sus más que famosas redondillas. Puede considerarse "La canción de Nerea" de la famosa novela de Gil Polo, como fuente y modelo de la poesía de la monja mexicana. $\mathrm{El}$ argumento es igual, como lo son los giros, las maneras expresivas, efectismos concepcionistas etc. Interesante sería un estudio comparativo de estos dos poetas: el tiempo no me lo permite ahora y ya será en una otra ocasión. Sólo quiero citar algunos versos de la poetisa :

"Hombres necios que acusáis

a la mujer sin razón, sin ver que sois la ocasión de lo mismo que culpáis ; si con ansia sin igual solicitáis su desdén, ¿ por qué queréis que obren bien si las incitáis al mal? 
La más sublime Poetisa de América y del Siglo XVII Sor Juana Con el favor y el desdén tenéis condición igual, quejándoos, si os tratan mal, burlándoos, si os quieren bien. Opinión ninguna gana, pues la que más se recata si no os admite, es ingrata, y si os admite, as liviana. Dan vuestras amantes penas a sus libertades alas, y después de hacerlas malas las quereis hallar muy buenas. ¿Pues para qué os espantáis de la culpa que tenéis?

Queredlas cual las hacéis, o hacedlas cual las buscáis."

Sin duda alguna, Sor Juana tiene una mayor destreza dialéctica y es más sobria que Gil Polo, pero sus redondillas tienen indudablemente ese origen y responden a la tradición concepcionista. Góngora, Calderón de la Barca y Gil Polo... Todo esto la adscribe a la tradición de la poesía española. Nada de la poesía de Sor Juana queda sin explicación dentro del área de la poesía peninsular y se comporta como un poeta más, eso sí, de genio mucho superior al de todos los que en España hacían versos en su tiempo.

Clara está la presencia de Calderón en sus comedias, en sus loas y sobre todo en sus Autos Sacramentales, en los que se encuentran los versos que más honran el numen de la poetisa. Sus Villancicos, que ocupan lugar considerable en su obra, tenían 
así mismo larga historia entre los españoles. En estos villancicos da entrada como actores a elementos populares y hasta indígenas que hablan su idioma azteca, como lo hiciera Lope de Vega y sobre todo Góngora, que hacían participar a rústicos de habla sayagüesa, a gitanos con sus intercalaciones verbales de caló, y a negros con su rudimentaria sintaxi. Todas estas indicaciones nada arguyen contra el valor de la poesía de la monja mexicana: Queda su poesía y queda su personalidad, descollando entre todos los poetas de su tiempo y al par de los excelentes de tiempos mejores.

La poesía de esta monja admirable, es una poesía de su tiempo y de su tiempo español y sólo se diferencia de sus contemporáneos de habla castellana en que, para su gloria, les hace a todos ventaja inigualable por su mayor inspiración, por su milagroso ingenio, por su retórica más depurada y perfecta. Vinculada queda su poesía al tronco de la poesía española, como hermosa rama florida y llena de gracias.

Sor Juana vive en nuestros días por medio de su poesía y de su literatura y por medio de su mensaje de amor.

He tratado de exponer en pocas palabras la vida, la obra, y las características de esta poetisa mexicana y de su tierna poesía, casi como volando o picando por aquí y allá, y no sé si lo que he escrito ha sido una ensalada, como decía a veces la misma Sor Juana Inés de la Cruz :

$$
\begin{aligned}
& \text { "Y haremos una ensalada } \\
& \text { de algunos picados versos, } \\
& \text { más salada que una hueva } \\
& \text { y más fresca que un invierno". }
\end{aligned}
$$

